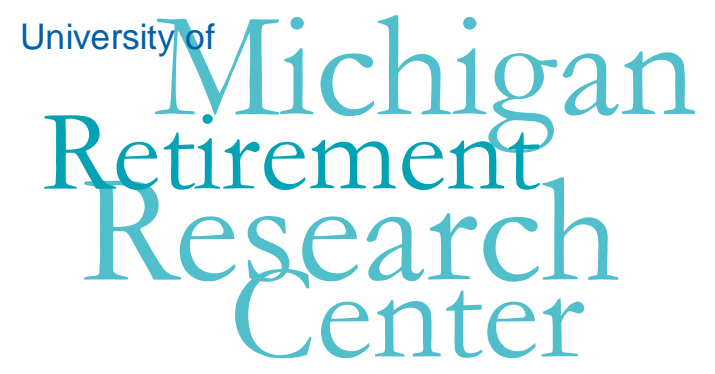

Working Paper

WP 2010-225

\title{
Mortgage Contract Decisions and Mortgage Distress: Family and Financial Life-Cycle Factors
}

\author{
Frank P. Stafford and Elena Gouskova
}

\begin{tabular}{|c|c|}
\hline $\mathrm{M}$ & $\mathrm{R}$ \\
\hline $\mathrm{R}$ & $\mathrm{C}$ \\
\hline
\end{tabular}

Project \#: UM10-09 


\title{
Mortgage Contract Decisions and Mortgage Distress: Family and Financial Life-Cycle Factors
}

\author{
Frank P. Stafford \\ University of Michigan \\ Elena Gouskova \\ University of Michigan \\ September 2010
Michigan Retirement Research Center
University of Michigan
P.O. Box 1248
Ann Arbor, MI 48104
http://www.mrrc.isr.umich.edu/
(734) 615-0422

\section{Acknowledgements}

This work was supported by a grant from the Social Security Administration through the Michigan Retirement Research Center (Grant \# 10-M-98362-5-01). The findings and conclusions expressed are solely those of the author and do not represent the views of the Social Security Administration, any agency of the Federal government, or the Michigan Retirement Research Center.

Regents of the University of Michigan

Julia Donovan Darrow, Ann Arbor; Laurence B. Deitch, Bingham Farms; Denise Ilitch, Bingham Farms; Olivia P. Maynard, Goodrich; Andrea Fischer Newman, Ann Arbor; Andrew C. Richner, Grosse Pointe Park; S. Martin Taylor, Gross Pointe Farms; Katherine E. White, Ann Arbor; Mary Sue Coleman, ex officio 


\title{
Mortgage Contract Decisions and Mortgage Distress: Family and Financial Life-Cycle Factors
}

\begin{abstract}
The U.S. economy experienced a dramatic rise in the price of owner occupied housing during 1999-2007, and then a precipitous decline from 2007 through 2009. In this paper we utilize data from the Panel Study of Income Dynamics (PSID) during 1999-2009 to study first the factors and borrowing decisions which were related to the run-up and then to see how these diverse positions in owner-occupied housing related to the subsequent difficulties and mortgage distress as of 2009. Our research shows that much of the rise and subsequent difficulties were concentrated among younger and less educated homeowners, and that the difficulties were also concentrated in selected real estate markets where home owners were allocating a substantial share of their income to debt service and other home related outlays such as taxes, utilities, and insurance. This pattern of high costs to support a housing position is interpreted as the result of a speculative price run-up supported by the joint decisions of the homeowners and their lenders. In this process the older population took on more mortgage debt than in prior years and may now have less capacity to support help to other adult family members living outside the home.
\end{abstract}




\section{Introduction and Motivation}

Owner-occupied housing is the major asset in many households' portfolios and across a wide span of the life cycle. Housing wealth is an important determinant of consumption and saving behavior of households and is often correlated with savings and better overall financial management. A family's investment decision in housing may have profound implications for all those within it and for the economy at large. Investment in housing is often financed through a mortgage contract, a feature crucial for understanding the causes and consequences of the recent crises. In particular, the downturn in housing prices and associated delinquencies on mortgages are generally considered to be the major cause of the crisis in credit markets that subsequently spilled into the other sectors of the economy.

Housing services are the consumption dimension, but on the financial side recent research (Hurst and Stafford, 2004; Cooper, 2009) supports own home as primarily playing a collateral or liquidity role - in contrast to the wealth effects found for non-pension holdings of stocks (Juster, Lupton, Smith and Stafford, 2006). In the Hurst-Stafford framework there are two motivations for exercising the option to refinance a mortgage. There is a traditional financial motivation to realize a net worth gain and possibly an asset reallocation when an existing mortgage can be refinanced at a lower interest rate. A second motivation for exercising the refinancing option is to tap into equity and 'borrow up' to support consumption. Exercising this consumption option can lead to refinancing to a higher rate of interest. A third motivation to refinance can be to cover cash flow requirements from home ownership which are induced by interest, tax and utility costs. This refinancing can be thought of as a liquidity option. That is, refinancing to a position in housing which embodies a wider set of and higher level of costs. These are costs beyond those related to normal predicted consumption, based on income and family composition. This speculative financing based on expected appreciation appears to have played a major role in the housing market turbulence during 2001-2009.

\section{Mortgage Concepts}

Use of refinancing or holding a larger mortgage can be thought of as an investment or speculative motivation. Related to liquidity, this tapping into perceived equity gains from rising home prices can clearly be risky as changes in the family balance sheet are mixing with expense flows. In short, during 
the boom, families and their lenders more often took on a jointly speculative position leading to increased cash flow demands to cover housing costs - a potential motivation for refinancing as home prices rose. In part, higher marginal debt service costs were offset by interest deductibility on home mortgages. $^{1}$

The decisions to invest in housing and hold a substantial mortgage are usually associated with younger households (Flavin and Yamashita, 2002) as part of a life-cycle approach to consumption and asset management (Campbell and Viciera, 2002; Deaton, 2001), but the housing boom of 1999-2005 induced many of those 60 years or older to hold more housing and have greater mortgage debt than for prior cohorts. In 1986, 20.4 percent of owners age 65-79 held a mortgage on their home, and by 2005 this had increased to 35.8 percent. A study by Apgar and Di (2006) reports that mortgage debt owed by older households nearly quadrupled between 1989 and 2001. In 2001, after accounting for inflation, the typical household headed by someone 65 or older had $\$ 44,000$ in mortgage debt, compared with $\$ 12,000$ in 1989 (Apgar and $\mathrm{Di}, 2006$ ). Among the factors contributing to increased home debt among elderly are changes in the tax code in 1986 and the increase in real estate property values in the 1990s. Additionally, reports in the press suggest that equity-rich, cash poor elderly homeowners in need to pay off debt, cover medical expenses, or help out the kids had been an attractive target for predatory mortgage lenders.

Whether this increased housing debt by the elderly presents a problem for their financial well being ultimately depends on how much wealth and income older borrowers have. One aspect is clear, however. Even at the lower mortgage rates, by 2007 the mortgage debt payments as well as other expenses for insurance and taxes had become a rising share of family income compared to earlier periods. This was most pronounced in specific urban markets. With rising home expenses and a greater cost of home debt servicing, elderly homeowners, many of whom are on fixed or limited incomes, may find themselves in a financially constrained or even distressed liquidity situation should there be a reversal in home prices.

\footnotetext{
${ }^{1}$ Another type of liquidity problem can arise when the price and induced tax increases lead to cash flow problems as in Florida and California. This sounds like an Adam Smith difference between value in use and value in exchange or a mixture of price of housing services versus financial dimensions!
} 
A traditional source of financial help has been help from relatives living outside the family unit, particularly across generations. Elderly parents finding themselves in financially distressed situations could turn to their adult children for help. But more often, it has generally been that elderly parents, financially more secure than their young adult children, are the source of help. In the recent crises with the rise in unemployment and collateral losses in the owner-occupied housing market, many families are experiencing financial distress and face the risk of foreclosure. As a result, financial well being of the elderly can be negatively affected as younger adult family members are increasingly seeking help from their parents. The potential support from elders may be limited, if these families are themselves constrained via prior housing commitments, and any implicit sharing or insurance arrangements will not work. One perspective on family finances is that of an informal or implicit insurance arrangement. ${ }^{2}$ In times of need intra-family transfers (across separate households) can stabilize economic well-being and attenuate economic stress.

Here we explore some of the questions outlined above by using the new data being collected as of spring - fall of 2009 in the long-standing, nationally representative Panel Study of Income Dynamics (PSID) of now approximately 9,000 families and 24,000 individuals living within these families. What makes the PSID data particularly well-suited to address these questions from a household perspective? It is the rich set of variables traditionally collected, including those on housing and wealth holdings and basic geospatial measures. These measures, together with the new questions on foreclosure and mortgage distress added in 2009 and on fixed/adjustable mortgage rates added in 2007 and 2009, are now available as a supplemental file on the PSID website.

\footnotetext{
${ }^{2}$ For a theoretical and empirical assessment of the insurance aspects of the family, see Altonji, Hyoshi and Kotlikoff, 1997.
} 


\section{Net Worth and Emerging Patterns of Home Mortgage Participation and Asset Ownership}

Here we present basic patterns of household net worth for those headed by a person age 65 and older and of those at midlife course, age 40-49, along with age profiles of participation on the home mortgage market over time. In Table 1 it can be seen that over the period, 2001-2007, those age 65 and older experienced a substantial rise in the constant dollar value of their net worth. The median value of net worth rose modestly but was generally quite stable. The rise in net worth of families age 65-79 has been documented elsewhere. ${ }^{3}$ The younger or midlife group age 40-49, which could be thought of as including the 'younger generation,' and likely to seek help from the elders in times of need also had substantially more net worth as of 2007 compared to 2001 . On the other hand, financial net worth, cash or that which can be readily converted into cash, shows no growth at the mean or median, 2001-2007, for those 65 or older, and, in fact, declined modestly.

For those age 40-49 the mean financial wealth shows no clear improvement, 2001-2007, and the median financial wealth shows a low and declining real value, 2001-2007. Of some concern is that moving toward 2007 the liquid financial net worth is declining, especially relative to overall net worth, and is persistently low and declining, especially at the median, for those families age 40-49. The median for this age group was persistently under $\$ 10,000$ (\$2007). As financial vicissitudes arise, these midlife course families have limited liquid reserves to deal with negative financial shocks ${ }^{4}$. Moreover, the 'First National Bank of Granddad' had not increased its overall reserves nor the reserves relative to overall portfolio value.

\footnotetext{
${ }^{3}$ The average net worth of those age 65-79 more than doubled in constant dollars from 1984-2001 and the income relative to Census Needs also rose strongly for this group, especially for those in better health. See Grafova, McGonagle and Stafford, 2005 "Functioning and Well-Being in the Third Age,1986-2001," in The Crown of Life: Dynamics of the Early Post-Retirement Years (Jacquelyn B. James and Paul Wink, eds.) , 2006.

${ }^{4}$ The 2007 value of non-collateralized debt, especially burdensome in a cash flow crisis, shows that of the families who hold any had a total balance averaging $\$ 21,500$. See 'Trends in Household Wealth Dynamics, 2005-2007.' Technical paper Working Paper Series, September, 2009.

http://psidonline.isr.umich.edu/Publications/Papers/tsp/2009-03_Trends_in_Household_Wealth.pdf
} 
Table 1

Household Net Worth ${ }^{5}$ (NW) and Financial Net Worth (FNW), 2001-2007 (\$2007)

\begin{tabular}{||l|c|c|c|c||}
\hline \hline AGE & 2001 & 2003 & 2005 & 2007 \\
\hline $65+$ & & & & \\
\hline NW Mean & 463.5 & 486.4 & 488.5 & 575.5 \\
\hline NW Median & 218.5 & 204.3 & 208.1 & 237.1 \\
\hline FNW Mean & 238.8 & 255.0 & 222.8 & 237.7 \\
\hline FNW Median & 48.7 & 48.4 & 42.5 & 42.0 \\
\hline $40-49$ & & & & \\
\hline NW Mean & 267.8 & 257.4 & 306.5 & 367.2 \\
\hline NW Median & 82.3 & 73.8 & 81.7 & 90.0 \\
\hline FNW Mean & 123.5 & 103.5 & 121.7 & 100.1 \\
\hline FNW Median & 9.7 & 8.0 & 8.2 & 8.0 \\
\hline \hline
\end{tabular}

Turning to home ownership, we present age profiles based on the full weighted sample of the PSID, 1979 to 2007. Figure 1 has the proportion of mortgage holding of home owners by age group, 25-34, 35$49,50-64$ and 65 and older. The top line is for those headed by a family age $25-34$, and just below are the families age 35-49. Both show the persistently high rates for those families headed by a 25-49 year old. The middle line is for families headed by a 50-64 year old. About half of these families held a mortgage from 1979 to the early 1990's and then the share of homeowners with a mortgage rose to about rose to about 70 percent after 1999.

\footnotetext{
${ }^{5}$ These are the same definitions as used in "Wealth Dynamics of American Families, 1984-1994," (Erik Hurst, Ming Ching Luoh and Frank P. Stafford), Brookings Papers on Economic Activity, 1998:I, p. 276-337. However, as of 1999 the value of IRA's in the PSID was obtained in a separate question sequence.
} 
The lowest line is for families headed by an individual age 65 or older. Over the period we can see a rise for older families from under $20 \%$ with a mortgage to about $30 \%$ by 2007 . Another reference point is the dip in mortgage holding in the early 1990's, a period with high mortgage rates, followed by a rebound in mortgage holding as rates came down in the mid and later 1990's.

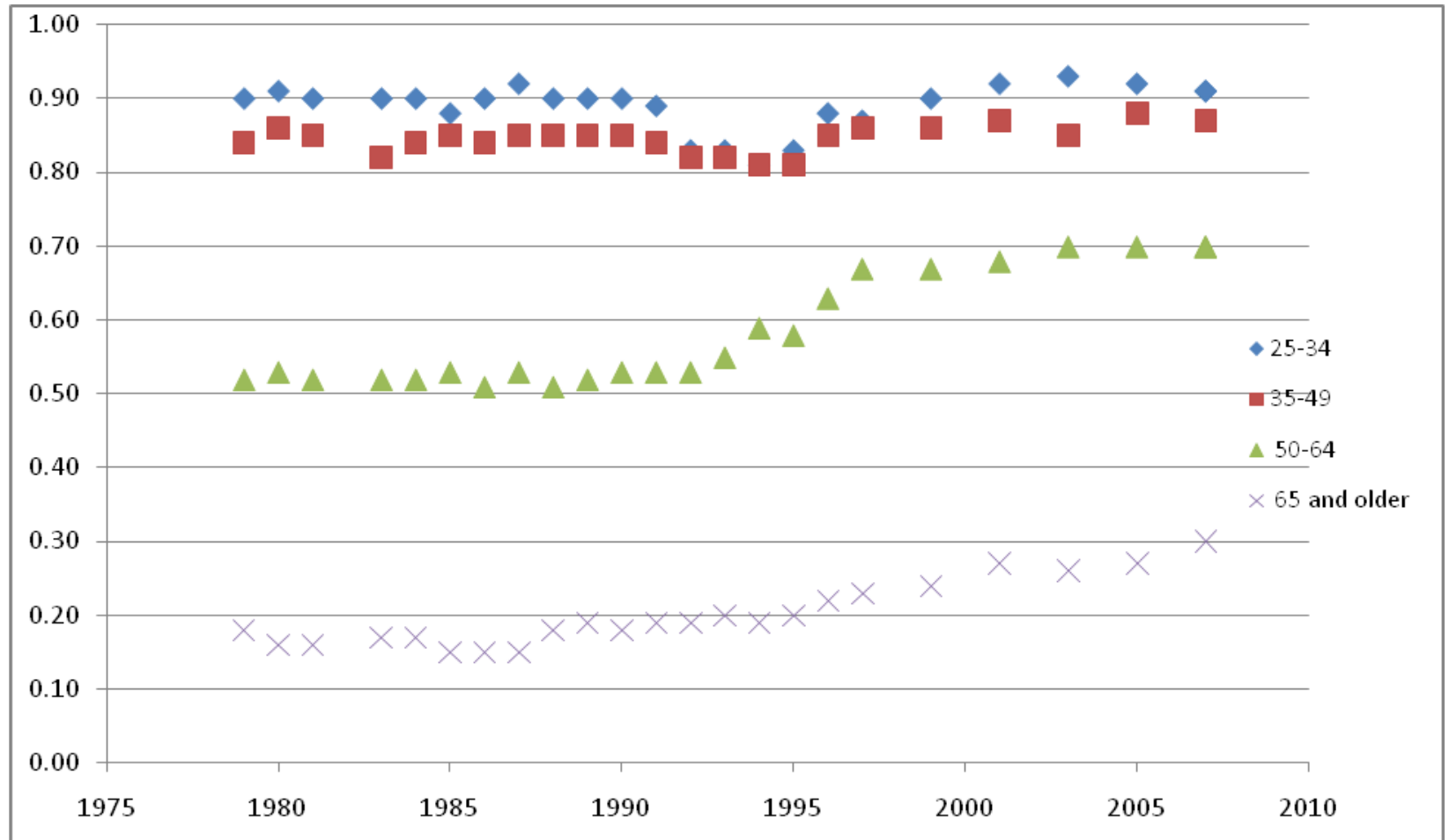

Figure 1

Percent of Home-owning Families Holding a Mortgage by Age of Homeowner

Over this time period second mortgages were in the set of financing arrangements. As shown in 


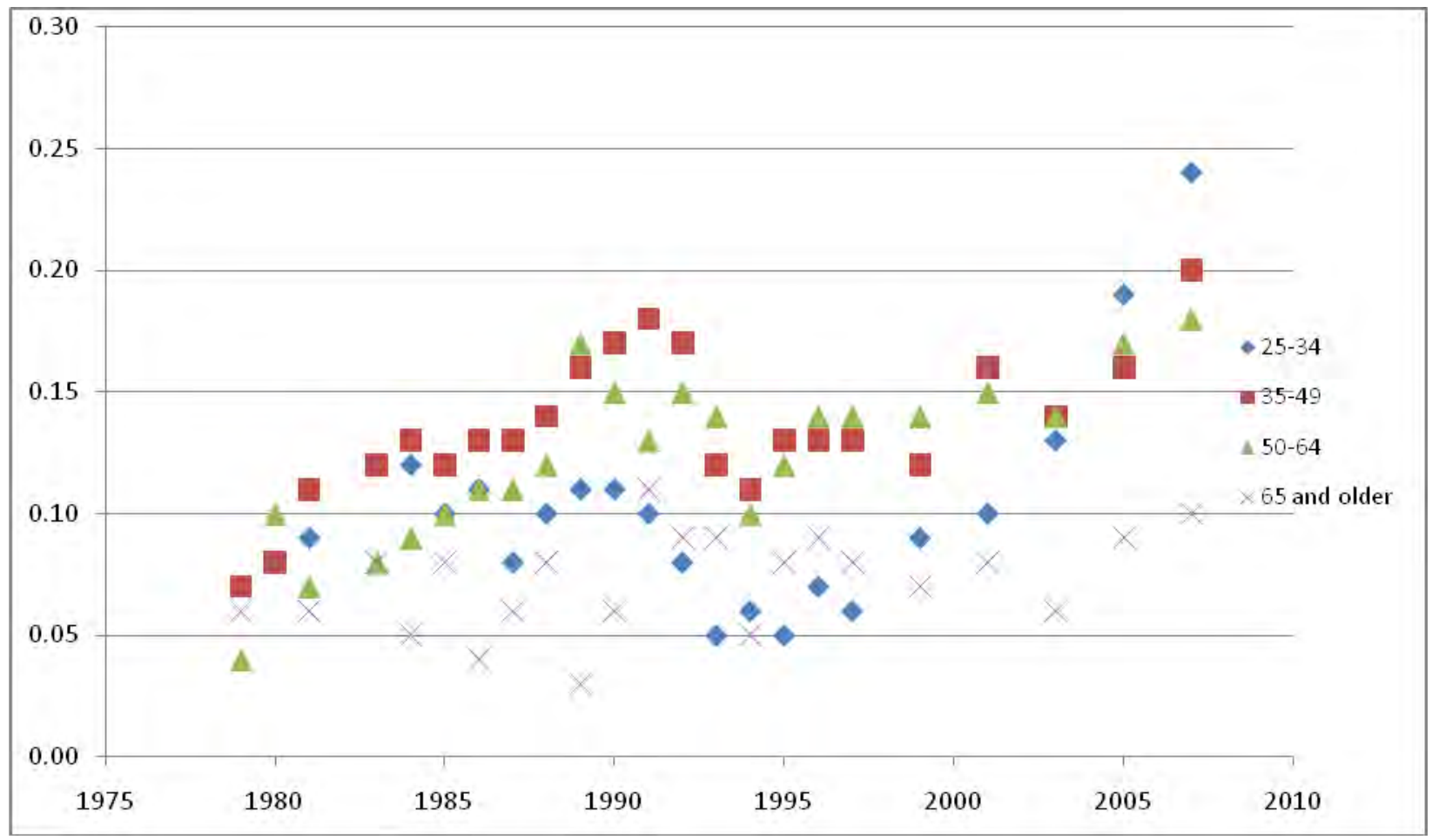

Figure 2

Second Mortgage Holding by Age of Homeowner

Figure 2, the pattern of second mortgages is quite erratic, but has an upward trend for those 35-64 up to the decline in mortgage rates in the mid-1990's and also the advent of expedited mortgage processing from that time forward. The use of a second mortgage makes sense for those wishing to draw out home equity when prevailing rates are high. They can keep a low rate on their first mortgage and pay the higher rate on a smaller, incremental borrowing. Despite the growth of refinancing choices, the second series also suggests the use of second mortgages was on the rise during 2003-2007. A third look is the cash flow dimension to homeownership. This is illustrated for 1993-2007 in Figure 3. 


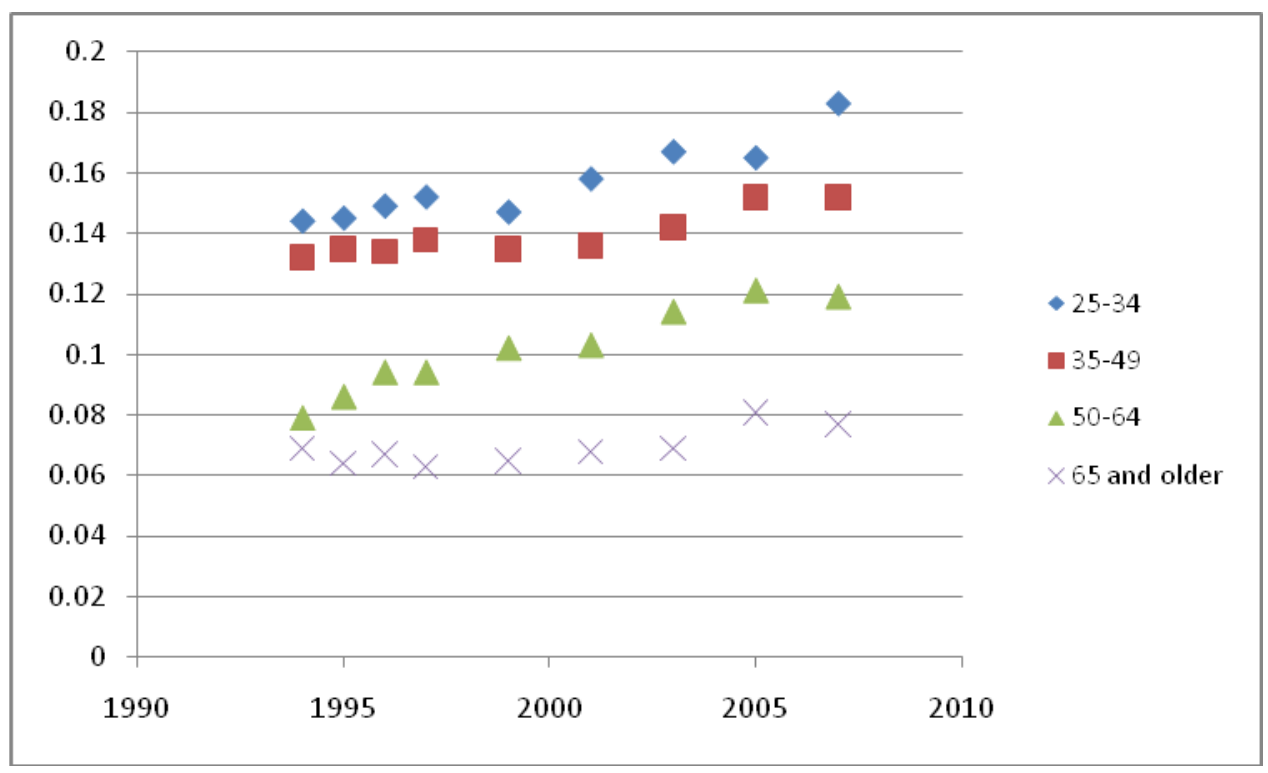

Figure 3

$50^{\text {th }}$ percentile of Housing Cost Relative to Family Income

Aside from a 2005-2007 modest attenuation for those 65 and older, we can see a general rise in the median share of family income going housing payments in 2001-2007. And the rise is steeper for the youngest group.

One related measure of housing and mortgage contract position is a micro level version of the Debt Service Ratio (DSR) maintained by the Federal Reserve Board. This aggregate index shows the upward movement in cash flow burden of mortgages up through 2007. At the micro level the PSID data show both a rising and dispersed ratio of mortgage debt to family income (DSR). Holding a high DSR is one measure of a family's housing risk. The expectation of additional future increases in home prices can be the motivation for enduring a higher cash flow burden. Expanding this to include all other housing related payments (taxes insurance, utilities,...) relative to family income, housing payments to income (HPI), provides another measure, as set out in Figure 3.

These are payments for interest on the first and second mortgage, and with rising house prices come rising real estate taxes, and along with utilities, the cash flow going into owner occupied housing was on the rise. Retrospectively, we may want to conclude that these were evident patterns of 'excess' in the housing and mortgage market. At the time of the upswing, observers could think - we are seeing the effect of the Baby Boom with a growth of families at their peak of income, and this is the early part of 
the cohort, and with those born toward the end (1964) of the boom, we will see a continued strong demand for housing ${ }^{6}$. Edward Gramlich (2007) noted that one aspect of the 1995-2005 U.S. housing pattern was higher ownership rates with a wider demographic distribution. The growth of persistent ownership, 1999-2005, is illustrated in Appendix Table A1 below. Some families persisted as renters and others, in addition to being new or continuing owners, took on very risky positions. Specifically, they (and their lenders) chose variable rate mortgages or ones with a balloon repayment and a short horizon, and the PSID panel data show this and other aspects of housing and mortgage decisions.

The intergenerational structure of the PSID supports a unique analysis of ownership patterns. To begin this analysis we selected all the families headed by an individual age 65 or older as of 2007 . Then we determined if and how many children of the head and \or wife, under age 65, were also present in the 2007 sample. If none were found, the 65+ family was dropped from the subsample. In the other cases there were sometimes two or more adult child families under age 65, and occasionally there was one family headed by an individual under age 65 with two parental families with a head age 65 or older. We used the set of families with a head under age 65 as the reference point and if more than one 65+ family was present in 2007 we assigned the parental 65+ measures to each. See Table 2.

Table 2. The Ownership Patterns of those Age 65 and Older and Their Adult Children, 2007

\begin{tabular}{|l|c|c|c|}
\hline Child $\backslash$ Parent & Parent Owns & Parent Does Not Own & Total \\
\hline Child Owns & $63.8 \%$ & $12.77 \%$ & $76.60 \%$ \\
& $(969)$ & $(193)$ & $(1162)$ \\
\hline Child Does Not Own & $14.3 \%$ & $9.2 \%$ & $23.5 \%$ \\
& $(217)$ & $(140)$ & $(375)$ \\
\hline Total & $78.1 \%$ & $21.9 \%$ & $100.0 \%$ \\
& $(1186)$ & $(333)$ & $(1519)$ \\
\hline
\end{tabular}

This sample, as well as the sample of adult children with more than one $65+$ parental family to 'lean $\mathrm{on}^{\prime}$, is not large enough for separate analysis. This raises the more empirically important topic of

\footnotetext{
${ }^{6}$ In Appendix Table 1 we show the share of homeowners by year in the different age groups form the weighted PSID data.
} 
multiple adult children potentially being connected to a single 65+ family - essentially a multiple dependence - potentially creating a greater demand in the insurance role for the $65+$ family. The across generation case counts as of 2007 and their home ownership status is set out in Table 2 . There is a higher overall ownership in this subgroup of intergenerational pairs than in the full population (about $77 \% \vee 67 \%)$, and there is a modest positive correlation in ownership across the generations, even though the child generation includes many who are younger and less likely to own. Whether this modest intergenerational ownership correlation implies a strong family risk position will depend not just on ownership per se, but the mortgage arrangements and other aspects of the families' assets and cash flow position. We now turn to the mortgage positions and their correlation.

\section{The Presence of NTM's and the Cash Flow Position}

What measures are clear indicators of a risky housing position prior to the declines in the market? A widely used measure has been loan to value ratios. The existing PSID data show that the 2005 loan to value ratios as a measure of the homeowner's leverage position are problematic. A high LTV, well above a 'safe' level of $80 \%$ or more in home equity at the point of mortgage settlement, was often driven downward by rapid home price increases, producing an ex post 'safe' mortgage. By 2007 the normal strong relationship between permanent income and the house value (not shown here) became much weaker. Then going forward to 2009, we will see some of the ex ante 'safe' mortgages become 'under water' with the rapidly declining home values, 2007-2009. By 2009 most of the acute declines had ended, and the net equity position ex post can be observed as an outcome. Which families are these who are experiencing this 'collateral damage'? How strongly does the 2007 housing payments to income, likely a better ex ante risk measure, relate to such an outcome?

To define non-traditional mortgages or NTM's, we first consider the families as of 2007. One measure, NTM1, is simply whether the rate on the primary mortgage was reported to be adjustable. 


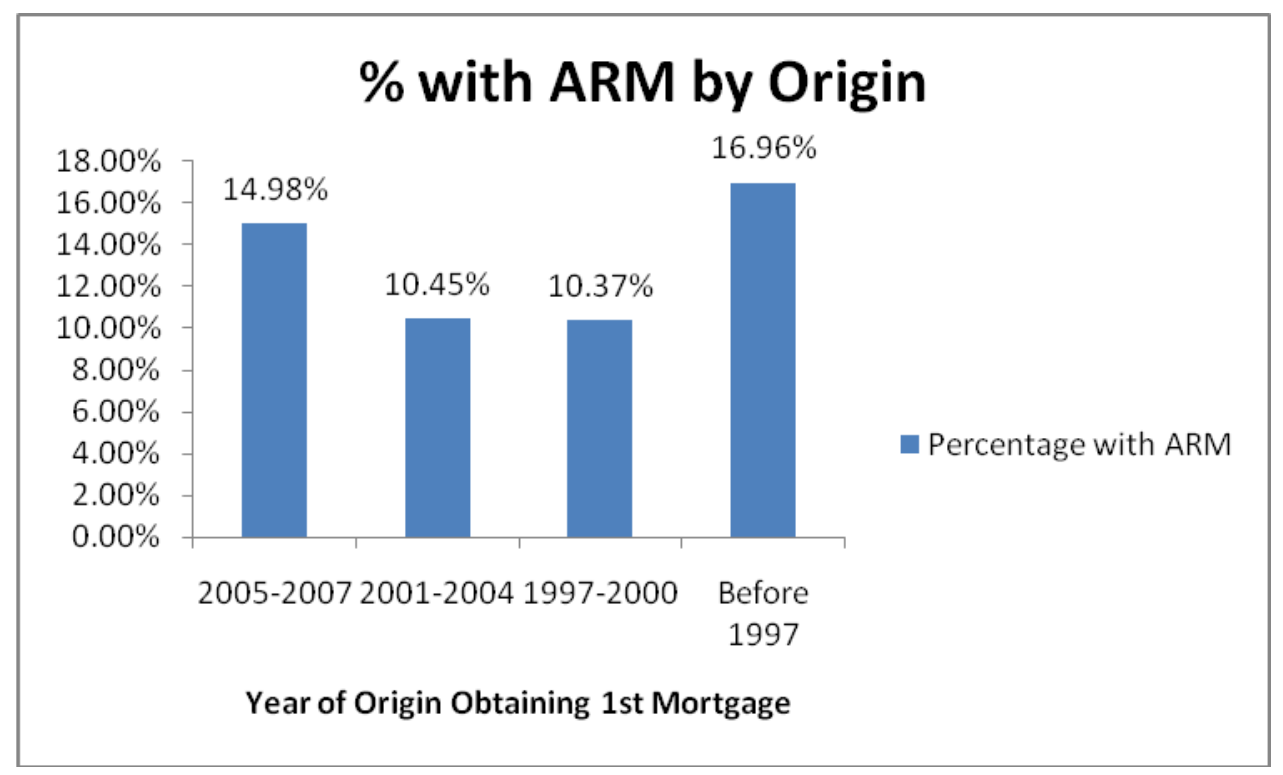

Figure 4

Adjustable Rate Mortgage as the Primary Loan by Year of Origin

From Figure 4 above the share of the 2007 mortgages which were variable rate mortgages is rising from 1997 to 2007. The rise is even stronger given the reports were from a March to December field period in 2007, and that the 2001-2004 and 1997-2001 are for 4 year intervals. Also the share of ARMS is highly concentrated in certain states as can be seen from the following Figure 5. Here, California, Florida and Arizona are states in which there was a strong run up in the Case-Shiller repeat home sales index - and had the cities leading the parade of declining prices from mid-2007 to mid 2009 (Phoenix, Miami, Tampa Bay, San Diego, Los Angeles and San Francisco). By comparison, Texas shows a far lower rate of refinancing and Dallas shows an attenuated price run up and a far lower subsequent decline in home prices, 2007-2009.

One interpretation is that refinancing was part of speculative leveraging to participate in the housing market concentrated in certain urban housing markets. So, if true, this is consistent with speculative refinancing as a third motive to the simple taxonomy of the financial and consumption options refinancing model of Hurst and Stafford. The refinancing here could support the cash flow needed to hold the asset during an anticipated price run up. Under these conditions refinancing during the housing boom represents a type of NTM, here NTM2. Figure 5 shows the patterns of refinancing by state, and the states with large increases in the Case-Shiller Index for the major urban areas showed the greatest percent of refinancing. Much of the refinancing in California and Arizona was in the period 2004-2007. 


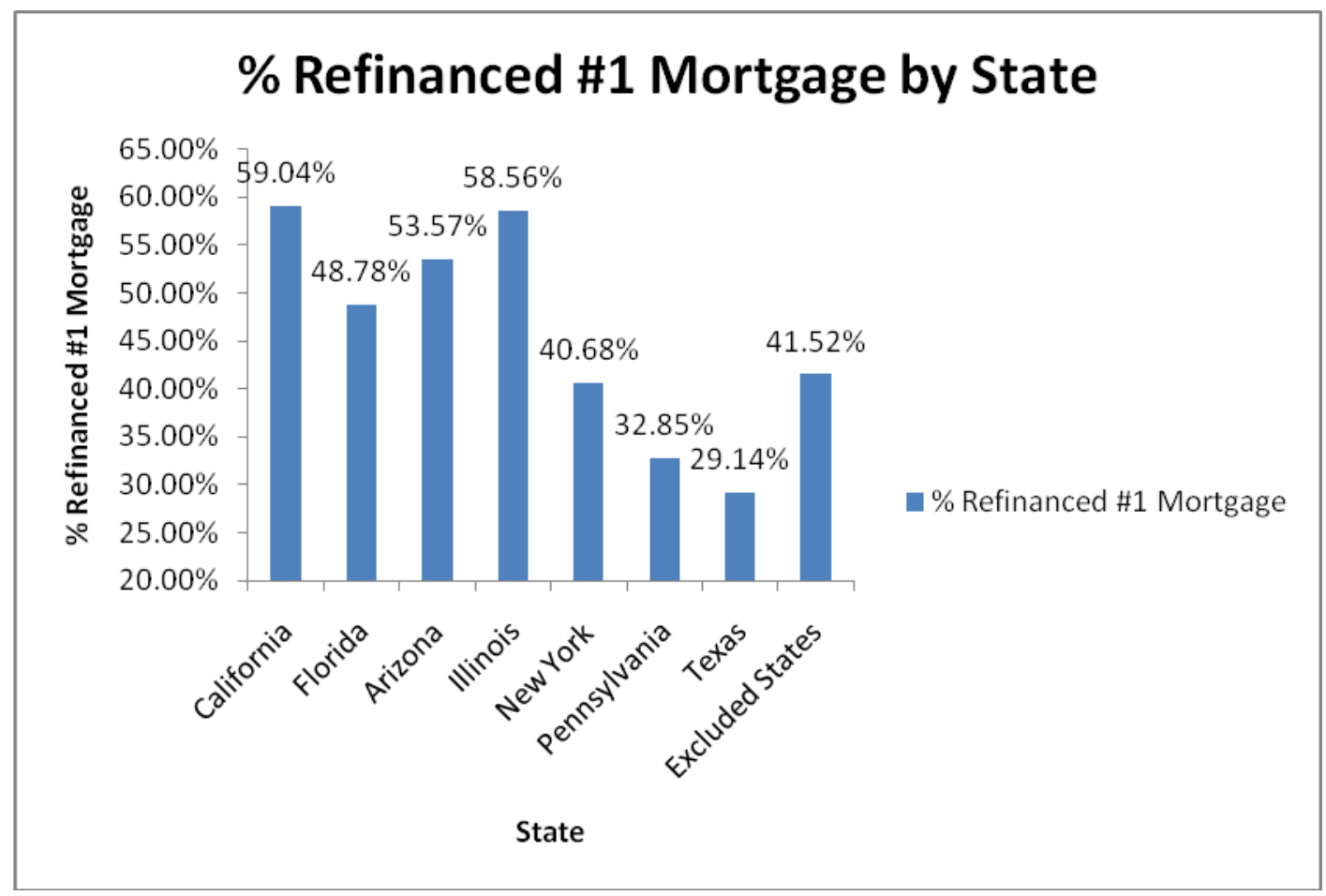

Figure 5

Percent Refinancing First Mortgage by State, 2004-2007

A higher incidence of refinancing among those with less education was also a pattern.

\section{\% Refinanced \#1 Mortgage by Education}

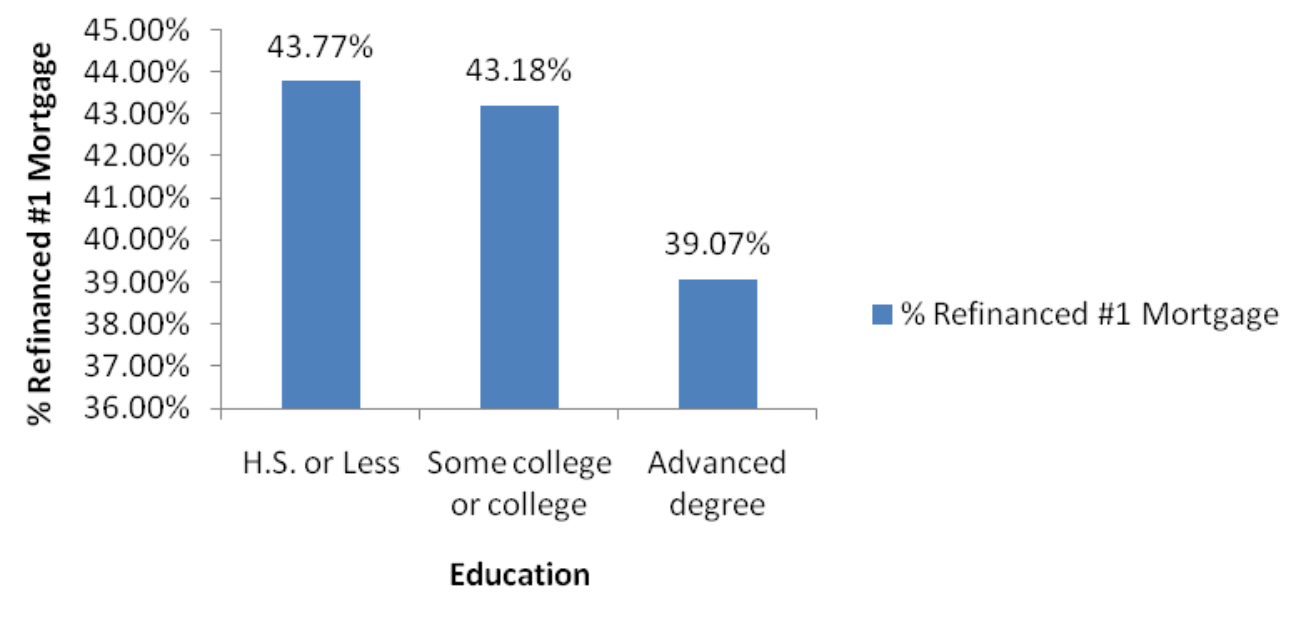

Figure 6

Percent Refinancing First Mortgage by Education of the Head, 2004-2007 
Such refinancing was quite common among those familes with a head age 65 or older. Homeowners in the age cohort 55-64 had the highest percentage of ARMs. Income is negatively correlated with ARMs, indicating that the higher the income, the less likely a homeowner obtained an ARM.

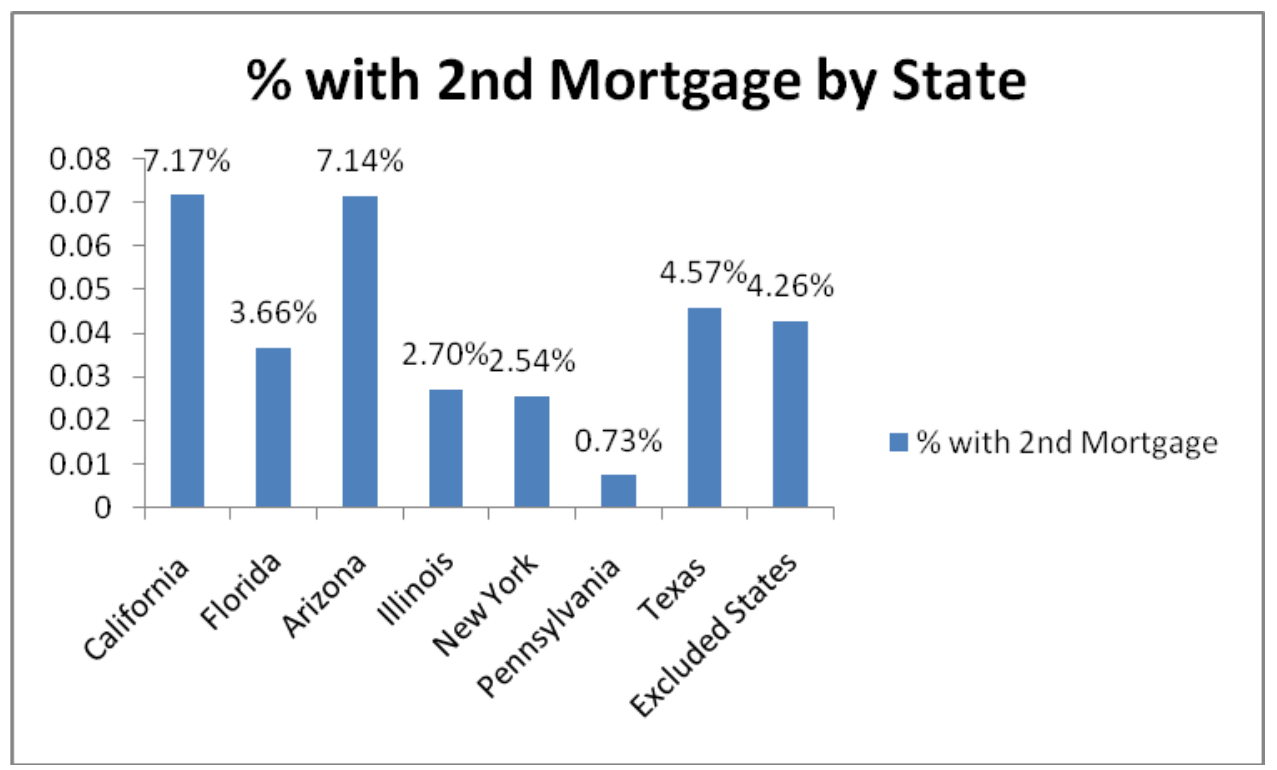

Figure 7

Percent with Second Mortgage by State, 2007

According to Figure 7, homeowners residing in California and Arizona were most likely to obtain a second mortgage for their homes. In contrast only $0.7 \%$ of mortgages in Pennsylvania were second mortgages, which was the lowest percentage among all the states. The trend in second mortgages parallels that of ARMs in regards to the year of second mortgage origin. The majority of homeowners obtained their second mortgages either before 1997 or between the years 2005 and 2007. In contrast to ARMs, there is a negative correlation with age and second mortgages. While only $1.2 \%$ of 65 and older homeowners obtained a second mortgage, $8.1 \%$ of homeowners younger than 35 years old had a second mortgage.

Only 3.6\% of homeowners with an educational attainment level of a high school degree or less obtained a second mortgage. The higher the family unit's income, the less likely they were to obtain a second mortgage. By contrast, those refinancing mortgages were somewhat more likely to be those 
with higher incomes. Those who obtained their first mortgage between years 2001 and 2004 were more likely to refinance, with $50.0 \%$ of mortgages obtained from 2001 to 2004 being refinanced and $43.0 \%$ of mortgages obtained from 2005 to 2007 being refinanced.

As we saw in Figure 3 above there was a general rise in the share of income going to support homeowner expenses. In addition many homeowners had refinanced in the near term, especially in selected states. Then given the positions of families with respect to housing as of 2007 , how important are $2007 \mathrm{HPI}$ (housing payments relative to family income) and other 2007 mortgage measures in predicting the various outcomes in 2009 - foreclosure, falling behind in payments, mortgage modification, and expecting to fall behind in the next 12 months?

\section{Outcomes, 2007-2009}

Here we show how these ex ante risk positions played out as the housing market and the wider economy deteriorated, 2007-2009. For this we have used the early files in 2009 which measure a set of mortgage distress indicators, or adverse outcomes. These range from no observed problems to modest reported risk of payment problems in the next 12 months, to having fallen behind substantially in making payments, the need to modify the mortgage because of payment problems (not normal refinancing), and then actual foreclosure since 2007. Specifically, we have explored the following outcomes:

1 Foreclosure, 2007-2009. The case count here is based on those who report being in foreclosure as of the 2009 interview (A27F3) plus those who report a foreclosure in the 2001-2009 time window ( A37F1). To provide a measure of recent foreclosures this overall group gets reduced by 2 factors. First are the foreclosures, 2001-2006 (from A37F2), which occurred before we collected information on whether the mortgage rate was variable and other aspects of the mortgage. Another group is excluded because the property foreclosed upon was not their primary residence (A37F5) (1=own home, 2= investment property, $3=$ vacation home/condo, 7 = other specify).

2 Falling behind. This is based on the variable (A27F1) $1=$ yes, $5=$ no from the pdf of the questionnaire. There are no values of ' 8 or 9 '. Here $1=1$, and all others $=0$.

3 Next 12 Months (A27FOR6) fall behind? 1=very likely, $3=$ somewhat likely, $5=$ not at all likely. Here we have an ordered logit with three categories for the dependent variable: 1,3 , and other.

4 Mortgage Modification ( A24FOR5 (1=yes; $5=$ no) $1=1,5$ and other $=0$.

5 Under water. Here we have the cases where a dollar value of the home was reported. The unfolding bracket cases are likely to create classification problems. The ratio is (for valid dollar value of home value on the market - excluding bracket range values $s$ and 'don't know's') the sum of (A24MOR1 + A24 MOR2)/A20 = sum of mortgage balances / house value (value of house if sold today). This was converted into 1-0 under water = sum of mortgages $/ \mathrm{hv}>1.00$ or not. 
We have developed logistic regression models for outcomes 1-5. The estimates for foreclosures (Table 3) are limited by the small case counts on recent foreclosures. Variables showing a relationship to the distress measures are age, education, and 2007 share of income allocated to housing payments. Consider one 2009 outcome for which we have results. As of the date of the interview in 2009 had the family taken steps to have their mortgage modified (see Table 4). This provides a view on what was applied in the other outcome variables in that it has the 2007 variables used to predict the set of outcomes as of 2009. The preliminary results indicate - not surprisingly - that having more income and fewer family members (higher per capita family income) as of 2007 reduces the probability of falling behind. Those who are marred have a higher probability of being behind in payments. ${ }^{7}$ Also, cities of 100,000 and larger have an effect (more likely to fall behind). If the head was working as of the date of interview in 2007 this reduces the risk of falling behind, more education reduces the risk of falling behind, and African Americans are more likely to be falling behind. Related to the intergenerational aspect, those over 65 were far less likely to have difficulties - despite the substantial shift to mortgage holding by those $65+$. So the older generation may be in a better position to help their adult children.

Two interesting results on the financial side are that those on an original mortgage and those who financed further back in time are less likely to be behind - consistent with a speculator interpretation. Whether a recent refi, Case-Shiller Index (CSI) (dummy codes for rate of decline for the big urban markets. 2007-2009), both have substantial effects on the probability of falling behind in mortgage payments as of 2009. Including the CSI dummies displaces the effect of city size and region. Further, adding house payments to family income as of 2007 (HPI high) generally reduces the CSI relationship for the outcomes. The HPI variable, denoted as housing payment ratio $<=1$, is the ratio of these payments relative to 2007 total family income (excluding a few extreme values where the ratio was 1.0 or greater). For Table 5 (behind in mortgage payments) and Table 7 ('under water') the CSI variable has a persistent effect when HPI is part of the equation. In Table 4 (mortgage modified) and Table 6 (expect to fall behind in the coming 12 months), the effect of the CSI variable is clearly reduced when HPI is added to the model. ${ }^{8}$ This is summarized in Table 8.

\footnotetext{
${ }^{7}$ Not surprisingly, net worth as of 2007 (excluding housing) has a large negative effect.

${ }^{8}$ The foreclosure questions cover a wider time interval, 2001-2009, but here we wanted to have a dependent variable with a time frame parallel to the other measures, 2007-2009.
} 
To review, for Tables 3-6, in each regression, excluding the housing payments dummy generally leads to substantially larger and more statistically significant effects for the Case-Shiller Index categories. This is consistent with the interpretation that selected urban housing markets were subject to a substantial price run-up and that this was reflected in the increased share of family income needed to service the debt and other costs associated with home owning. In the context of a speculative run-up, at some point few additional, net entrants to the market were present to support the continued price rise. Once prices ceased to rise, the motivation to persist as a speculator began to wane on the part of the homeowners and the lenders, and the fall was underway.

Table3

Logistic Regression of Being Recently in Foreclosure

\begin{tabular}{lcc} 
Variable & Estimate & Standard Error \\
\hline Intercept & $9.2531^{* * *}$ & 2.391 \\
Head is male (0/1) & -0.4654 & 0.8442 \\
Age head 25-34 (0/1) & 0.4932 & 1.0377 \\
Age head 35-49 (0/1) & 1.1509 & 0.7754 \\
Age head 50-64 (0/1) & 1.1473 & 0.7344 \\
Black (0/1) & 0.4832 & 0.5839 \\
Married (0/1) & -0.0697 & 0.8598 \\
Less than high school (0/1) & 1.2107 & 0.8872 \\
High school diploma (0/1) & $1.3879^{*}$ & 0.8001 \\
Some college (0/1) & $1.8678^{* *}$ & 0.7749 \\
Family size & $0.2706^{*}$ & 0.1499 \\
Head working now (0/1) & $-1.48^{* * *}$ & 0.468 \\
North East (0/1) & -0.632 & 0.647 \\
Midwest (0/1) & -0.657 & 0.581 \\
South (0/1) & -0.7083 & 0.604 \\
Largest city 500,000 or more (0/1) & 0.4226 & 0.7453 \\
Largest city 100,000-499,999 (0/1) & 0.684 & 0.4587 \\
Whether Original mortgage (0/1) & 0.1169 & 0.4218 \\
Year of mortgage origination & -0.00011 & 0.000596 \\
Area not in Case-Shiller (0/1) & 2.5048 & 1.7478 \\
Case-Shiller 07-09 decline $>=15 \%$ but $<35 \%$ & 2.6934 & 1.7975 \\
Case-Shiller 07-09 decline >=35\% & 1.9296 & 1.7618 \\
Housing payment ratio & $3.8794^{* * *}$ & 0.9886 \\
\hline Summary statistics & & \\
N : & 3432 & \\
\hline
\end{tabular}


Table 4

Logistic Regression of Mortgage Modification

\begin{tabular}{lcc} 
Variable & Estimate & Standard Error \\
\hline Intercept & $-3.2418^{* * *}$ & 0.5124 \\
Head is male (0/1) & 0.3158 & 0.2322 \\
Age head 25-34 (0/1) & 0.272 & 0.2777 \\
Age head 35-49 (0/1) & 0.0536 & 0.249 \\
Age head 50-64 (0/1) & -0.2011 & 0.2383 \\
Black (0/1) & $0.4164^{* *}$ & 0.2069 \\
Married (0/1) & $-0.6653^{* * *}$ & 0.2258 \\
Less than high school (0/1) & $0.6325^{* * *}$ & 0.2178 \\
High school diploma (0/1) & $0.438^{* * *}$ & 0.168 \\
Some college (0/1) & 0.1881 & 0.1752 \\
Family size & $0.1827^{* * *}$ & 0.0544 \\
Head working now (0/1) & $-1.28 \mathrm{E}-01$ & $1.96 \mathrm{E}-01$ \\
North East (0/1) & $2.51 \mathrm{E}-01$ & $2.10 \mathrm{E}-01$ \\
Midwest (0/1) & $1.02 \mathrm{E}-01$ & $1.90 \mathrm{E}-01$ \\
South (0/1) & -0.1764 & 0.1924 \\
Largest city 500,000 or more (0/1) & 0.1867 & 0.2165 \\
Largest city 100,000-499,999 (0/1) & 0.23 & 0.1523 \\
Whether Original mortgage (0/1) & -0.0185 & 0.1346 \\
Year of mortgage origination & 0.000032 & 0.000187 \\
Area not in Case-Shiller (0/1) & -0.2519 & 0.245 \\
Case-Shiller 07-09 decline $>=15 \%$ but <35\% (0/1) & -0.5038 & 0.3106 \\
Case-Shiller 07-09 decline $>=35 \%(0 / 1)$ & 0.2261 & 0.2831 \\
Housing payment ratio & $2.8808^{* * *}$ & 0.3997 \\
\hline Summary statistics & & \\
N: & 2731 & \\
\hline & & \\
& & \\
\hline
\end{tabular}


Table 5

Logistic Regression of Falling Behind the Mortgage, 2009

\begin{tabular}{lcc} 
Variable & Estimate & Standard Error \\
\hline Intercept1 & $-6.9577^{* * *}$ & 0.9011 \\
Head is male (0/1) & $-0.6931^{*}$ & 0.3941 \\
Age head 25-34 (0/1) & $1.7338^{* * *}$ & 0.5149 \\
Age head 35-49 (0/1) & $1.6251^{* * *}$ & 0.4719 \\
Age head 50-64 (0/1) & $1.3632^{* * *}$ & 0.4551 \\
Black (0/1) & $0.7323^{* * *}$ & 0.2599 \\
Married (0/1) & -0.0106 & 0.3952 \\
Less than high school (0/1) & $1.6297^{* * *}$ & 0.3139 \\
High school diploma (0/1) & $1.0582^{* * *}$ & 0.2748 \\
Some college (0/1) & $0.7718^{* * *}$ & 0.2909 \\
Family size & $0.2338^{* * *}$ & 0.0699 \\
Head working now (0/1) & -0.372 & 0.265 \\
North East (0/1) & 0.220 & 0.316 \\
Midwest (0/1) & 0.201 & 0.278 \\
South (0/1) & 0.1276 & 0.2759 \\
Largest city 500,000 or more (0/1) & 0.3147 \\
Largest city 100,000-499,999 (0/1) & $0.6113^{*}$ & 0.2161 \\
Whether Original mortgage (0/1) & $0.4157^{*}$ & 0.1942 \\
Year of mortgage origination & -0.2244 & 0.000271 \\
Area not in Case-Shiller (0/1) & -0.00004 & 0.4913 \\
Case-Shiller 07-09 decline >=15\% but <35\% (0/1) & $1.10^{* *}$ & 0.6018 \\
Case-Shiller 07-09 decline >=35\% (0/1) & 0.276 & 0.5218 \\
Housing payment ratio & $1.2039^{* *}$ & 0.5297 \\
\hline Summary statistics & $2.9982^{* * *}$ & \\
N: & & \\
\hline & 2730 & \\
\hline
\end{tabular}




\section{Table 6}

Ordered Logistic Regression of Expectation to Fall Behind on Mortgage Payments in the Next 12 Months (Very Likely, Somewhat Likely, Not Likely)

\begin{tabular}{lcc} 
Variable & Estimate & Standard Error \\
\hline Intercept1 & $-5.8647^{* * *}$ & 0.4997 \\
Intercept2 & $-4.0302^{* * *}$ & 0.4851 \\
Head is male (0/1) & -0.1122 & 0.2345 \\
Age head 25-34 (0/1) & $1.1501^{* * *}$ & 0.3162 \\
Age head 35-49 (0/1) & $1.1811^{* * *}$ & 0.2886 \\
Age head 50-64 (0/1) & $1.0468^{* * *}$ & 0.2786 \\
Black (0/1) & $0.4381^{* *}$ & 0.1876 \\
Married (0/1) & -0.3474 & 0.2282 \\
Less than high school (0/1) & $1.4954^{* * *}$ & 0.1968 \\
High school diploma (0/1) & $0.8378^{* * *}$ & 0.1618 \\
Some college (0/1) & $0.575^{* * *}$ & 0.1695 \\
Family size & $0.252^{* * *}$ & 0.0484 \\
Head working now (0/1) & 0.106 & 0.194 \\
North East (0/1) & -0.0284 & 0.204 \\
Midwest (0/1) & -0.0973 & 0.182 \\
South (0/1) & 0.2808 & 0.1722 \\
Largest city 500,000 or more (0/1) & -0.0932 & 0.2195 \\
Largest city 100,000-499,999 (0/1) & 0.0631 & 0.1425 \\
Whether Original mortgage (0/1) & -0.1 & 0.1251 \\
Year of mortgage origination & $-0.00043^{* * *}$ & 0.000145 \\
Area not in Case-Shiller (0/1) & 0.1298 & 0.2567 \\
Case-Shiller 07-09 decline >=15\% but <35\% (0/1) & -0.0494 & 0.3127 \\
Case-Shiller 07-09 decline >=35\% (0/1) & 0.2893 & 0.2949 \\
Housing payment ratio & $3.1102^{* * *}$ & 0.3759 \\
\hline Summary statistics & & \\
N : & 2716 & \\
\hline
\end{tabular}




\section{Table 7}

Logistic Regression of Being "Under Water"

\begin{tabular}{lcc} 
Variable & Estimate & Standard Error \\
\hline Intercept & $-4.277^{* * *}$ & 0.676 \\
Head is male (0/1) & $-0.6496^{*}$ & 0.3434 \\
Age head 25-34 (0/1) & $0.6688^{*}$ & 0.348 \\
Age head 35-49 (0/1) & 0.3073 & 0.328 \\
Age head 50-64 (0/1) & -0.4557 & 0.3285 \\
Black (0/1) & 0.0115 & 0.3113 \\
Married (0/1) & $0.6567^{* *}$ & 0.3329 \\
Less than high school (0/1) & $0.5989^{* *}$ & 0.286 \\
High school diploma (0/1) & $0.4232^{* *}$ & 0.2008 \\
Some college (0/1) & 0.1255 & 0.2077 \\
Family size & -0.0179 & 0.0687 \\
Head working now (0/1) & $1.06 * * *$ & 0.314 \\
North East (0/1) & -0.334 & 0.287 \\
Midwest (0/1) & 0.358 & 0.219 \\
South (0/1) & -0.22 & 0.228 \\
Largest city 500,000 or more (0/1) & -0.2359 & 0.2706 \\
Largest city 100,000-499,999 (0/1) & 0.0313 & 0.1917 \\
Whether Original mortgage (0/1) & 0.0535 & 0.1646 \\
Year of mortgage origination & -0.00024 & 0.000238 \\
Area not in Case-Shiller (0/1) & -0.1956 & 0.3098 \\
Case-Shiller 07-09 decline >=15\% but <35\% (0/1) & -0.5264 & 0.4007 \\
Case-Shiller 07-09 decline >=35\% (0/1) & $1.1858^{* * *}$ & 0.3368 \\
Housing payment ratio & $4.7299 * * *$ & 0.5104 \\
\hline Summary statistics & & \\
N : & 2546 & \\
\hline
\end{tabular}


Table 8

Logistic Regression Coefficients on Mortgage Distress Measures:

Price Declines and Housing Payments/Income

\begin{tabular}{|l|c|c|c|c|}
\hline & Outside Case-Shiller & Case-Shiller 15-34\% & Case-Shiller $>35 \%$ & Housing Pay Ratio \\
\hline Recent Foreclosure & $2.505(1.748)$ & $2.693(1.798)$ & $1.930(1.762)$ & $3.879(0.989)^{* * *}$ \\
\hline Mortgage Modified & $0.801(1.147)$ & $1.387(1.231)$ & $0.474(1.246)$ & \\
\hline & $-0.252(0.245)$ & $-0.504(0.311)$ & $0.226(0.283)$ & $2.881(0.400)^{* * *}$ \\
\hline Have Fallen Behind & $1.10(0.491)$ & $0.276(0.602)$ & $1.204(0.522)^{* *}$ & $2.998(0.5230)^{* * *}$ \\
\hline & $0.910(0.459)$ & $0.539(0.554)$ & $1.234(0.490)^{* *}$ & \\
\hline Expect Fall Behind & $0.130(0.257)$ & $-0.049(0.313)$ & $0.289(0.295)$ & $3.110(0.376)^{* * *}$ \\
\hline & $-0.018(0.237)$ & $0.080(0.291)$ & $0.573(.267)^{* *}$ & \\
\hline 'Under Water' & $-0.196(0.310)$ & $-0.526(0.401)$ & $1.186(0.337)^{* * *}$ & $4.730(0.510)^{* * *}$ \\
\hline & $-0.526(0.257)^{* *}$ & $-0.466(0.341)$ & $0.923(0.281)^{* * *}$ & \\
\hline
\end{tabular}

\section{Outcomes and Intergenerational Connections - Discussion}

We can clearly see the patterns describing those who fell into mortgage distress of various forms. In Tables 3-7 the younger age groups are the ones more likely to have mortgage difficulties as are those with less education. African-American families are also more like to have experienced distress in some form. With the exception of the small set of cases actually in recent foreclosure, in the Logistic models set out in Tables 3-7 the baseline model which included all but the housing payments ratio showed a substantial effect of being in a Case-Shiller city with a house price decline of 35 percent or more. When the measure of house payments to family income was added to the model, the effect of the Case-Shiller housing price decline variables was generally reduced. This is summarized in Table 8. In all the models which include the Housing Payment Ratio as of 2007, there are strong effects toward a greater risk of foreclosure and other mortgage distress measures. The strong connection of the high cash service burden on housing can inform future assessments of rising risk in residential housing. Committing a high 
share of income to housing is an indication that the family expects a price rise to reward their current payment burden. This was often not borne out.

Having documented the changing patterns and price risk position for each age group, and the factors shaping mortgage distress as of 2009, we explored the correlation across the intergenerational pairs reported in Table 2. We know there is an IG correlation in home ownerships (0), so the both own cell $(\mathrm{O}-\mathrm{O})$ along with the both rent $(\mathrm{R}-\mathrm{R})$ represent most of the cases. The main interest is in the $\mathrm{O}-\mathrm{O}, \mathrm{R}-\mathrm{O}$, and O-R groups, and the most important to study of the three is the O-O group. Here we explored the extent to which the different risk measures (HPI, NTM, CSI categories, and financial net worth) are positively or negatively correlated for owners across the generations. The preliminary findings suggest potential resources for intra-family assistance. Namely, the co-variation in risky outcomes as of 2009 was quite low.

Future work with these data from PSID and the Health and Retirement Study will provide additional insight on the intergenerational connection. For now one can see a number of important patterns - all the adverse outcomes were inversely related to the reported overall life satisfaction of the respondent in 2009 and over 16 percent of the sample holding a mortgage anticipated difficulties making mortgage payments in late 2009-2010. Whether or not these expectations were borne out, future waves of PSID data will allow an assessment of the extent to which these expectations influenced family consumption and savings behavior. Other factors to be studied include the impact of mortgage distress on financing college costs ${ }^{9}, 2009$ and forward.

\section{References}

Apgar W. C. and Zhu Xiao Di (2006),"Housing Wealth and Retirement Savings: Enhancing Financial Security for Older Americans," in the Oxford Handbook of Pensions and Retirement Income, edited by Gordon L Clark et al., Oxford University Press.

Altonji, Joseph, Fumio Hayashi and Laurence Kotlikoff, "Parental Altruism and Intra-Vivos Transfers," Journal of Political Economy, December, 1997, pp. 1121-1166.

Campbell, John Y. and Luis Viceira, Strategic Asset Allocation: Portfolio Choice for Long-Term Investments, Clarendon Press, Oxford, 2002.

\footnotetext{
${ }^{9}$ See Appendix A, Table A2.
} 
Deaton, Angus, Understanding Consumption, Clarendon Press, Oxford, 1991.

Gramilch, Edward M., The Subprime Crisis: America's Latest Boom and Bust, Urban Institute, Washington, D.C., 2007.

Cooper, Daniel, Essays on Housing Wealth and Consumer Behavior, Ph.D. dissertation, University of Michigan, Department of Economics, 2009.

Flavin, Marjorie and Takishi Yamashita, "Owner-Occupied Housing and the Composition of the

Portfolio," American Economic Review, March, 2002, p. 345-362.

Hurst, Eric and Frank P. Stafford, "Home is Where the Equity Is: Mortgage Refinancing and Household Consumption, Journal of Money Credit and Banking, December 2004, p.985-1014.

Juster, F. Thomas, Joseph Lupton, James P. Smith and Frank P. Stafford, "The Decline in Household Savings and the Wealth Effect," Review of Economics and Statistics, 2006). 


\section{Appendix on Pre-Crisis Patterns}

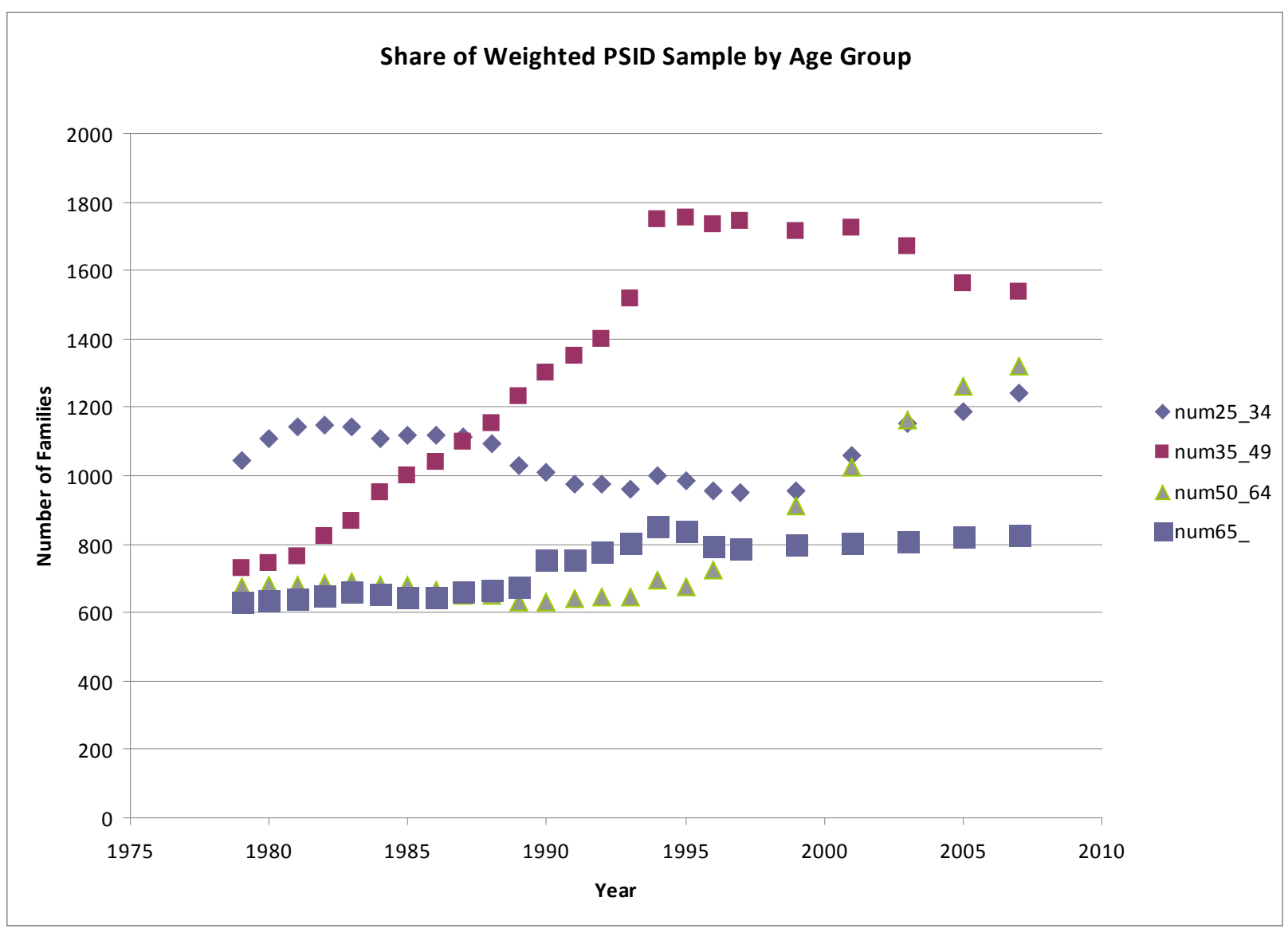

Table A1. The Rise of Persistent Home Ownership, 1999-2005

\begin{tabular}{|l|l|l|l|}
\hline \multicolumn{1}{|l|}{1989 - 1995 -- All Respondents Ages 30-60 } \\
\hline & Don't Own 1989 & Own 1989 & Total \\
\hline Don't Own 1995 & $25.66 \%$ & $4.74 \%$ & $30.40 \%$ \\
\hline Own 1995 & $10.74 \%$ & $58.86 \%$ & $69.60 \%$ \\
\hline Total & $36.40 \%$ & $63.60 \%$ & $100 \%$ \\
\hline
\end{tabular}

\begin{tabular}{|l|l|l|l|}
\hline \multicolumn{5}{|l|}{1999 - 2005 -- All Respondents Ages 30-60 } \\
\hline & Don't Own 1999 & Own 1999 & Total \\
\hline Don't Own 2005 & $22.39 \%$ & $5.07 \%$ & $27.47 \%$ \\
\hline Own 2005 & $10.81 \%$ & $61.72 \%$ & $72.53 \%$ \\
\hline Total & $33.20 \%$ & $66.80 \%$ & $100 \%$ \\
\hline
\end{tabular}




\begin{tabular}{|l|l|l|l|}
\hline \multicolumn{4}{|l|}{1989 - 1995 -- Black Respondents Ages 30-60 } \\
\hline & Don't Own 1989 & Own 1989 & Total \\
\hline Don't Own 1995 & $47.64 \%$ & $4.19 \%$ & $51.83 \%$ \\
\hline Own 1995 & $10.99 \%$ & $37.17 \%$ & $48.17 \%$ \\
\hline Total & $58.64 \%$ & $41.36 \%$ & $100 \%$ \\
\hline
\end{tabular}

\begin{tabular}{|l|l|l|l|}
\hline \multicolumn{4}{|l|}{1999 - 2005 -- Black Respondents Ages 30-60 } \\
\hline & Don't Own 1999 & Own 1999 & Total \\
\hline Don't Own 2005 & $39.03 \%$ & $6.42 \%$ & $45.45 \%$ \\
\hline Own 2005 & $12.14 \%$ & $42.41 \%$ & $54.55 \%$ \\
\hline Total & $51.17 \%$ & $48.83 \%$ & $100 \%$ \\
\hline
\end{tabular}

Table A2. Home Equity and Children's College Enrollment

\begin{tabular}{|l|l|l|l|l|l|}
\hline \multicolumn{2}{|c|}{ Percentages of Transition to Adulthood 2005 College Enrolled by Parental Home Equity } \\
\hline & $\begin{array}{l}\text { Less than } \\
\$ 25,000\end{array}$ & $\begin{array}{l}\$ 25,000- \\
\$ 99,999\end{array}$ & $\begin{array}{l}\$ 100,000- \\
\$ 199,000\end{array}$ & $\begin{array}{l}\$ 200,000- \\
\$ 349,999\end{array}$ & $\$ 350,000+$ \\
\hline Enrolled in College & 43 & 120 & 79 & 50 & 28 \\
\hline Total TA05 with PCG Own & 85 & 205 & 112 & 63 & 32 \\
\hline Weighted Percentage & $50.6 \%$ & $58.5 \%$ & $70.5 \%$ & $79.4 \%$ & $87.5 \%$ \\
\hline
\end{tabular}

Note: parents are renter \% in college = 32.6\% Source PSID, Transition to Adulthood, 2007. 